\title{
POLITICAL TRUST, SOCIAL TRUST, AND JUDICIAL REVIEW
}

\author{
Jason Mazzone ${ }^{1}$
}

\section{INTRODUCTION}

The fortieth anniversary of John Hart Ely's influential book, Democracy and Distrust: A Theory of Judicial Review, is a good occasion to focus less on democracy and more on distrust. Ely famously sets forth a process-based approach to judicial review, one he describes as "participation-oriented, representationreinforcing." 2 Under Ely's approach, majorities are generally entitled to rule and so judges should generally defer to the outcomes of majoritarian decision-making processes. Closer judicial scrutiny is warranted in two general circumstances, in order to correct process failures-failures that mean the process cannot be trusted and its outcomes become problematic. As Ely explains:

In a representative democracy value determinations are to be made by our elected representatives, and if in fact most of us disapprove we can vote them out of office. Malfunction [justifying judicial intervention] occurs when the process is undeserving of trust, when (1) the ins are choking off the channels of political change to ensure that they will stay in and the outs will stay out, or (2) though no one is actually denied a voice or a vote, representatives beholden to an effective majority are systematically disadvantaging some minority out of simple hostility or a prejudiced refusal to recognize commonalities of interest, and thereby denying that minority the protection afforded other groups by a representative system. $^{3}$

On this account, rather than seek to vindicate substantive

1. Albert E. Jenner, Jr. Professor of Law and Director, Program in Constitutional Theory, History and Law, University of Illinois Urbana-Champaign.

2. JOHN HART Ely, DEMOCRACY AND Distrust: A THEORY OF JUdicIAL REVIEW 87 (1980).

3. Id. at 103 (footnote omitted). 
constitutional values, the appropriate role of the Supreme Court (Ely's singular focus) is referee, ${ }^{4}$ intervening to keep clear the channels of political change and to ensure adequate protections for the interests of minorities. Ely dedicates his book to Earl Warren ${ }^{5}$-and for good reason. In his view, the Warren Court's jurisprudence, including in its apportionment cases and its robust invocation of equal protection, reflected an appropriate, processoriented role of judges - a role "foreshadowed" in footnote four of Carolene Products ${ }^{7}$ - in enhancing political participation and correcting against an untrustworthy process that results in disadvantages for racial and other minorities.

My focus in this short Essay is on a key element of Ely's motivating claim: that judicial review is warranted when governmental process is undeserving of trust. Although Ely takes the view that we can trust government (and trust each other) most of the time-with judicial review the remedy for untrustworthy processes $^{8}$ - he actually says very little about trust specifically. The word, "trust," itself appears just four times in the text." The word "distrust" appears only in the book's title. Strikingly, while Ely invokes trust, he does not draw at all upon the vast scholarly literature, in political science and allied fields, on conceptions and measurements of trust and its significance to democratic processes. In this Essay I suggest some ways in which that literature might helpfully enhance Ely's own account of judicial

4. Id. at 73

5. The dedication reads: "For Earl Warren. You don't need many heroes if you choose carefully." Id. at v.

6. Id. at 77 .

7. United States v. Carolene Prods. Co., 304 U.S. 144, 152 n.4 (1938). According to Ely, footnote four requires a "focus not on whether this or that substantive value is unusually important or fundamental, but rather on whether the opportunity to participate either in the political processes by which values are appropriately identified and accommodated, or in the accommodation those processes have reached, has been unduly constricted." ELY, supra note 2, at 77.

8. ELY, supra note 2, at 103.

9. See id. at 32-33 (describing the Court's reasoning in Bolling v. Sharpe that the Fifth Amendment Due Process Clause incorporates Equal Protection requirements as "gibberish" and explaining that "the members of the Reconstruction Congress might well have trusted themselves and their successors in a way they didn't trust the existing and future legislatures of the Southern states."); id. at 103 ("In a representative democracy . . . $[\mathrm{m}]$ alfunction occurs when the process is undeserving of trust"); $i d$. at 106 ("Courts must police inhibitions on expression and other political activity because we cannot trust elected officials to do so"); id. at 120 ("We cannot trust the ins to decide who stays out, and it is therefore incumbent on the courts to ensure not only that no one is denied the vote for no reason, but also that where there is a reason ... it had better be a very convincing one."). 
review. Of particular relevance to revisiting Ely's work on its fortieth anniversary is what social scientists report about changes in levels of trust that have that occurred over time. Ely's position that most of the time government can be trusted (and so courts should generally stay their hands) had an important public analog. The Warren Court era (1953-1969) corresponded to a period in which Americans themselves placed very high levels of trust in government - as well as in their fellow citizens. Since the time of the Warren Court, however, trust in government-and in particular in the federal government-has plummeted, as has the propensity of Americans to trust each other. These changes invite questions about Ely's thesis as Democracy and Distrust enters its fifth decade. How should we think about judicial review if, in fact, most of the time we don't trust government-or trust some governmental institutions far less than others - and we don't trust each other? What role, under those circumstances, should the courts play?

Part I provides an overview of conceptions and measurements of trust and of changing levels of trust over time. Part II suggests how changes in political trust might inform the role of courts. Part III explores the same issue with respect to social trust. A brief conclusion follows.

\section{TRUST: AN OVERVIEW}

There is a vast and growing social science literature on trust. This Part highlights the key aspects of that literature that can inform Ely's own account of judicial review and lay also the groundwork for reconsidering the role of courts today. My discussion is divided into two main sections, corresponding to two different kinds of trust: political trust and social trust. In a nutshell, political trust refers to trust individuals place in their government. Social trust, on the other hand, refers to trust that individuals place in their fellow citizens. The bulk of the discussion in this Part concerns political trust because it is especially relevant to Ely's project, but social trust is relevant, too, and therefore warrants at least brief attention.

\section{A. Political TRUst}

Political trust is a measure of the public's confidence in the institutions of government and in those who exercise political power. Social scientists report several key determinants of 
political trust, including procedural fairness (political trust is higher when individuals are involved (or believe they have been involved) in the mechanisms of government decision-making (and when people believe the government acts impartially and predictably)); perceptions of the overall quality of government (e.g., in its delivery of public services, checks on self-dealing and other forms of corruption, and adherence to protections for individual rights); and personal economic performance (the better we are doing financially the more likely we are to trust the government). ${ }^{10}$ Importantly, political trust is not monolithic: citizens might well trust some political institutions and actors more than they trust others. ${ }^{11}$

In drawing upon the social science literature on political trust to consider the role of courts and to assess Ely's own approach to judicial review, the most relevant findings can be summarized as several key points. While there are effects of political cycles, it is clear that political trust has declined since the period of the Warren Court. ${ }^{12}$ Importantly, though, despite regular reports that Americans have come to distrust "government," distrust today is directed only at certain governmental entities. Specifically, trust in Congress and the federal executive has sharply dropped since the Warren Court era. Trust in the federal judiciary, however, has held strong. In addition, and most importantly, trust in state and local government has remained high over time even as Americans have come to distrust the elected branches of the federal government. ${ }^{13}$ These developments, summarized in this section, should prompt a rethinking of applications of the Elyan approach to judicial review, the topic explored in Part II.

\section{i. Declining Trust in the Federal Government}

Serious efforts to measure levels of political trust began in

10. KeVin Vallier, Trust In A Polarized Age 70-74 (2021)

11. Surveys show, for example, that Americans today have generally positive views of the U.S. Supreme Court but view Congress far less favorably. See infra Part I.A.i.

12. Pew Rsch. Ctr., Public Trust in Government: 1958-2021 (May 17, 2021), https://www.pewresearch.org/politics/2021/05/17/public-trust-in-government-1958-2021 [https://perma.cc/8V9J-BVU7].

13. Megan Brenan, Americans' Trust in Government Remains Low, GALluP (Sept. 30, 2021), https://news.Gallup.com/poll/355124/americans-trust-government-remainslow.aspx [https://perma.cc/AYZ4-92X2] ("Americans have consistently expressed majority-level trust in their own state and local governments to handle problems in their area."). 
1958, five years into the Warren Court era. In 1958, the first year the National Election Study asked Americans about their trust in government, $73 \%$ of respondents said they trusted the federal government "always" or "most of the time."14 By the end of the Warren Court period, that figure had dropped: to $62 \%$ in 1968 and to $54 \%$ in $1970 .{ }^{15}$ In March of 1980 , the year Ely published Democracy and Distrust, just $27 \%$ of Americans reported trust in the national government. ${ }^{16}$ These declines were no secret: commentators were widely remarking on, and seeking to explain, the sharp drops in political trust. ${ }^{17}$

More recently, public trust in the federal government has declined even further. Surveys show that the overall level of trust in the federal government is now at "near-record lows;" 18 that a majority of Americans are dissatisfied with the direction the country is taking ${ }^{19}$ and that only a minority is satisfied with the way the nation is governed. ${ }^{20}$ "Dissatisfaction with government" tops the list of national problems survey respondents identify. ${ }^{21}$

Since the onset of the Great Recession in 2007, the share of Americans who say they trust the federal government to do what is right either just about always or most of the time has hovered near $20 \%$. This remains true today, with $2 \%$ [in 2020] saying they trust the government just about always and 18\% saying they trust the government most of the time. Nearly eight-in-ten $(79 \%)$ say they trust the federal government to do

14. Pew Rsch. Ctr., Public Trust in Government, supra note 12

15. $I d$.

16. Id.

17. See, e.g., Paul R. Abramson \& Ada W. Finifter, On the Meaning of Political Trust: New Evidence from Items Introduced in 1978, 25 AM. J. POL. SCI. 297 (1981), https://www.jstor.org/stable/2110854 [https://perma.cc/2XRG-SFES].

18. Pew Rsch. Ctr., Americans' Views of Government: Low Trust, but Some Positive Performance Ratings (Sept. 14, 2020), https://www.pewresearch.org/politics/2020/09/14/americans-views-of-government-lowtrust-but-some-positive-performance-ratings/ [https://perma.cc/U5LW-NFG9].

19. Id.

20. Jeffrey M. Jones, Frank Newport \& Lydia Saad, How Americans Perceive Government in 2017, GALLUP (Nov. 1, 2017), https://news.Gallup.com/opinion/pollingmatters/221171/americans-perceive-government-2017.aspx [https://perma.cc/ZFU3LQYB].

21. In a 2017 survey, "dissatisfaction with government" topped the list of national problems respondents identified, with $20 \%$ of Americans citing this as the most important problem the country faces; the next highest category was healthcare, cited by $10 \%$ of respondents. Frank Newport, Americans View Government as Nation's Top Problem in 2017, GALLUP (Dec. 19, 2017), https://news.Gallup.com/poll/224219/americans-viewgovernment-nation-top-problem-2017.aspx [https://perma.cc/S2W6-S8VA]. 
what is right either some of the time $(65 \%)$ or never $(14 \%){ }^{22}$

Half of Americans even believe "the federal government poses 'an immediate threat to the rights and freedoms of ordinary citizens." "23

Of course, the federal government is not a single entity. Other evidence sheds relevant light on Americans' views towards different federal governmental institutions. Since 1972, Gallup has polled Americans on their trust in the three federal branches. That evidence shows that levels of trust in Congress and the executive branch have both declined, while trust in the judiciary has remained high over time. In 1972, $71 \%$ of respondents expressed "a great deal" or a "fair amount" of "trust and confidence" in Congress. ${ }^{24}$ In 2020, that figure was $33 \% .{ }^{25}$ As to the executive branch, $73 \%$ of respondents in 1972 expressed "a great deal" or "fair amount" of trust; in 2020, the figure was $43 \%{ }^{26}$ For the federal judicial branch, however, there has been virtually no change: in 2020, $67 \%$ of respondents expressed "a great deal" or "fair amount" of trust and confidence in the judiciary, compared to $67 \%$ in $1972 .{ }^{27}$ Distrust of the federal legislature is reflected in other findings: incredibly, "Congress engenders the lowest confidence of any institution that Gallup tests, and Americans rate the honesty and ethics of members of Congress as the lowest among 22 professions in Gallup's" surveys. ${ }^{28}$ In a 2020 Gallup study asking Americans about the honesty and ethical standards of members of various professions, "[m]embers of Congress and car salespeople tie for last, with just $8 \%$ [of respondents] rating them highly." 29 Of all public

22. Pew Rsch. Ctr., Americans' Views, supra note 18, at 13.

23. Frank Newport, Half in U.S. Continue to Say Government Is an Immediate Threat, GALLUP (Sept. 21, 2015), https://news.Gallup.com/poll/185720/half-continue-saygov-immediate-threat.aspx [https://perma.cc/6TA4-H6SP].

24. Gallup, Trust in Government, https://news.Gallup.com/poll/5392/trustgovernment.aspx [https://perma.cc/JZ59-LLGG] (last visited Nov. 5, 2021).

25. Id. Gallup's figures are often higher than those reported in other surveys, likely because of differences in question wording. See John Tierney, Do You Trust Your State Government?, THE ATLANTIC (May 12, 2014), https://www.theatlantic.com/ politics/archive/2014/05/trust-your-state-government/362044/ [https://perma.cc/FFR4S8QA] (reporting that "Pew's question is more vague and general, Gallup's more specific about trust in the government's handling of policy problems, international and domestic").

26. Gallup, Trust in Government, supra note 24.

27. Id.

28. Jones et al., supra note 20.

29. Lydia Saad, U.S. Ethics Ratings Rise for Medical Workers and Teachers, GALLuP (Dec. 22, 2020), https://news.Gallup.com/poll/328136/ethics-ratings-rise-medical-workers- 
institutions, the military has the strongest level of support. ${ }^{30}$

The Supreme Court also consistently receives higher marks than do other institutions of the federal government and trust in the Court has not changed much over time. In 1973, 73\% of respondents expressed a "great deal" (20\%) "quite a lot" $(25 \%)$ or "some" $(28 \%)$ "confidence" in the Supreme Court; in 2020, the figure was $81 \%$ (with $18 \%$ expressing a "great deal," $22 \%$ expressing "quite a lot," and 41\% expressing "some" confidence) ${ }^{31}$ In a poll at the end of the Court's 2019 Term, 58\% of Americans expressed approval of the Justices' work, with minor differences between how Republicans and Democrats viewed the Court. ${ }^{32}$ Significantly, Americans have confidence in the Supreme Court even though politicians (themselves not trusted) and commentators regularly describe the court as illegitimate and are busily engaged in consideration of ways to reform it. ${ }^{33}$ Consider, for example, the recent amici brief by five

teachers.aspx [https://perma.cc/83QS-BDSE].

30. See Jim Norman, Americans' Confidence in Institutions Stays Low, GALluP (June 13, 2016), https://news.Gallup.com/poll/192581/americans-confidence-institutionsstays-low.aspx [https://perma.cc/T4HV-PMJJ] (reporting that in 2016, 73\% of respondents expressed "a great deal" or "quite a lot" of confidence in the military; the figure for Congress was $9 \%$ ).

31. Gallup, Confidence in Institutions, https://news.Gallup.com/poll/1597/ confidence-institutions.aspx [https://perma.cc/V2JN-W52A] (last visited May 12, 2021).

32. See Jess Bravin, Supreme Court Has Highest Public Approval in 11 Years, WALL ST. J. (Aug. 5, 2020), https://www.wsj.com/articles/supreme-court-has-greatest-publicapproval-in-11-years-11596662931? reflink=desktopwebshare_permalink

[https://perma.cc/4U9R-A7TK]. In a 2017 poll, $49 \%$ of respondents voiced approval of the "way the Court is handling its job" and $68 \%$ expressed a "a fair amount" or a "great deal" of trust and confidence in the Court. Gallup, Supreme Court, https://news.Gallup.com/poll/4732/supreme-court.aspx [https://perma.cc/GX8F-LCAS] (last visited May 12, 2021). Support for the Court can vary with current events. For example, support among Republicans for the Court increased after the confirmation of Neil Gorsuch while it dropped among Democrats. Jeffrey M. Jones, Trust in Judicial Branch Up, Executive Branch Down, GALluP (Sept. 20, 2017), https://news.Gallup.com/poll/219674/trust-judicial-branch-executive-branch-down.aspx [https://perma.cc/EZ2N-A6US].

33. See, e.g., Steven G. Calabresi \& James Lindgren, Term Limits for the Supreme Court: Life Tenure Reconsidered, 29 HARV. J. L. \& PUB. POL'Y 769, 822-30 (2006) (proposing a system of staggered, eighteen-year term limits for Supreme Court Justices); Jordain Carney \& Rachel Frazin, Court-Packing Becomes New Litmus Test on Left, THE HILL (Mar. 19, 2019, 6:00 AM), https://thehill.com/homenews/senate/434630-courtpacking-becomes-new-litmus-test-on-left [https://perma.cc/J2Z2-D8BJ] (discussing support for court packing among Democratic presidential candidates); Stephen M. Feldman, Court-Packing Time: Supreme Court Legitimacy and Positivity Theory, 68 BUFF. L. REV. 1519, 1523 (2020) ("If the Democrats sweep the November 2020 elections, gaining control of both houses of Congress and the presidency, they should add at least four Justices to the Court, increasing its size to thirteen. They should then nominate and 
Senators in a Second Amendment challenge to a New York law. ${ }^{34}$ The Senators wrote that " $[\mathrm{t}]$ he Supreme Court is not well. And the people know it. Perhaps the Court can heal itself before the public demands it be 'restructured in order to reduce the influence of politics.' Particularly on the urgent issue of gun control, a nation desperately needs it to heal." 35 Soon after taking office, President Biden created a commission of "a bipartisan group of experts" "to provide an analysis of the principal arguments in the contemporary public debate for and against Supreme Court reform, including an appraisal of the merits and legality of particular reform proposals." ${ }^{36}$

Trust in the national government tends to be higher among members of the political party that controls the White House. ${ }^{37} \mathrm{At}$ the same time, "Republicans are much more reactive than Democrats to changes in political power. Republicans express much higher levels of trust during Republican than during Democratic presidencies, while Democrats' attitudes tend to be more consistent, regardless of which party controls the White House." ${ }^{38}$ During the Trump administration, the number of Republicans expressing trust in the government was $28 \%$,

confirm four progressive Justices.”); Tracey E. George \& Chris Guthrie, Remaking the United States Supreme Court in the Courts' of Appeals Image, 58 DUKE L.J. 1439, 1442 (2009) (recommending increasing the size of the Supreme Court and hearing of cases in panels with the possibility of en banc review); Christopher Jon Sprigman, Congress's Article III Power and the Process of Constitutional Change, 95 N.Y.U. L. REV. 1778, 178081 (2020) (arguing in favor of Congress limiting the jurisdiction of federal and state courts on specific issues of law, for example on questions of campaign finance regulation); Russell Wheeler, Should we Restructure the Supreme Court?, BROOKINGS INST. https://www.brookings.edu/policy2020/votervital/should-we-restructure-the-supremecourt/ [https://perma.cc/PEC8-FZHW] (last visited Nov. 1, 2021) (discussing support for term limits and an increase in the number of seats).

34. Brief for Senator Sheldon Whitehouse, et al. as Amici Curiae Supporting Respondents, New York State Rifle \& Pistol Assoc'n, Inc. v. City of New York, 140 S. Ct. 1525 (2020) (No. 18-280), https://www.supremecourt.gov/DocketPDF/18/18 280/112010/20190812151259076_18-280bsacSenatorSheldonWhitehouse.pdf [https://perma.cc/2QY8-LMPJ].

35. Id. at 18 .

36. White House Briefing Room, President Biden to Sign Executive Order Creating the Presidential Commission on the Supreme Court of the United States (Apr. 9, 2021) whitehouse.gov/briefing-room/statements-releases/2021/04/09/president-biden-to-signexecutive-order-creating-the-presidential-commission-on-the-supreme-court-of-theunited-states/ [https://perma.cc/3C3N-CQSY].

37. Pew Rsch. Ctr., Beyond Distrust: How Americans View Their Government 20 (Nov. 23, 2015), https://www.pewresearch.org/wp-content/uploads/sites/4/2015/11/11-232015-Governance-release.pdf [https://perma.cc/3JYX-GMBK].

38. Id. at $19-20$. 
compared with $12 \%$ of Democrats. ${ }^{39}$ During the Obama presidency, one-third of Republicans said they were "angry" with the federal government, compared to $11 \%$ of Democrats; during the Trump administration, one-third of Democrats and $14 \%$ of Republicans said they were angry. ${ }^{40}$ Current views towards both the Democratic and Republican parties are also near historic lows. ${ }^{41}$ Party affiliation appears to have its most significant impact on trust in the executive branch. In a fall 2020 survey, while $33 \%$ of Republicans and 38\% of Democrats expressed trust in the Congress, $91 \%$ of Republicans and $6 \%$ of Democrats expressed trust in the executive branch, an 85-point difference likely reflective of partisan division during the Trump era. ${ }^{42}$

Besides trust, the Warren Court era corresponded with a strong belief on the part of Americans in fairness on the part of the national government - a belief that has also dissipated over time. In 1964, 64\% of Americans thought the federal government was "run for the benefit of all the people." ${ }^{43}$ Just $29 \%$ of Americans in that year said that the government was "pretty much run by a few big interests looking out for themselves." ${ }^{4} \mathrm{~A}$ decade later, in 1974 , only $25 \%$ of Americans took the view that the national government was run for the benefit of all. ${ }^{45}$ More recently, the figure has dropped to below $20 \% .{ }^{46}$ Correspondingly, while $30 \%$ of Americans in 1964 thought the national government was "run by a few big interests looking out for themselves," in recent years that figure has been higher than $90 \% .{ }^{47}$ Further, it is well established that fair elections generate political trust. ${ }^{48}$ Yet large numbers of Americans today do not trust federal election results. The 2020 presidential election is a troubling example: despite a complete absence of any evidence of electoral

39. Pew Rsch. Ctr., Americans' Views, supra note 18, at 5.

40. Id. at 16

41. Jones et al., supra note 20.

42. Lydia Saad, Trust in Federal Government's Competence Remains Low, GALLUP (Sept. 29, 2020), https://news.Gallup.com/poll/321119/trust-federal-governmentcompetence-remains-low.aspx [https://perma.cc/Y3M7-TRFS].

43. Pew Rsch. Ctr., Beyond Distrust, supra note 37 at 26.

44. Id.

45. $I d$.

46. Id.

47. See Voice of the People, Voter ANGer with Government AND the 2016 ELECTION 5 (2016), https://vop.org/wp-content/uploads/2016/11/Dissatisfaction Report.pdf [https://perma.cc/D9VK-SFQF].

48. VALLIER, supra note 10, at 240-41. 
irregularities, large majorities of Americans who voted for Donald Trump believe he was the actual winner of the presidential contest. ${ }^{49}$

It also bears emphasis that while Americans do not think much of Congress or the federal executive, they do hold the Constitution-and the system of government it creates-in unshakeable high regard. Surveys consistently show that large portions of the public oppose making significant changes to the Constitution $^{50}$ even as levels of support for the nation's charter vary somewhat among different demographic groups. ${ }^{51}$ Americans also remain very optimistic about the future of the country. ${ }^{52}$ In sum, we live with paradox: "Americans have lost

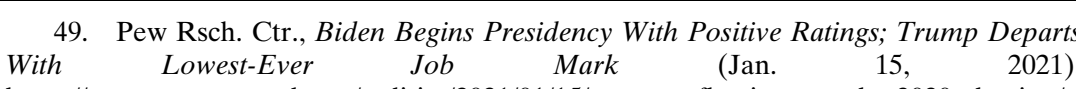
https://www.pewresearch.org/politics/2021/01/15/voters-reflections-on-the-2020-election/ [https://perma.cc/C39L-5C4C] (reporting that among Trump voters, 40\% say he "definitely" won and another $36 \%$ say he "probably" won the 2020 election).

50. See, e.g., Aspen Ideas Festival, Does the US Constitution Still Work for 21st Century America?, PENN SCHOEN BERland POLL (July 9, 2010), https://www.slideshare.net/tarekrizk/psb-constitution-poll-for-aspen-ideas

[https://perma.cc/3ESD-LZP4] (reporting that $60 \%$ of respondents took the view that the Constitution "is timeless and should be changed minimally" while only $32 \%$ answered that the document "needs significant updates" even while only $25 \%$ of respondents were satisfied with the way the government functions today and nearly $70 \%$ answered that "the Government today is functioning WORSE than intended" by the Framers); Nicholas Stephanopoulos \& Mila Versteeg, The Contours of Constitutional Approval, 94 WASH. U. L. REV. 113, 138 (2016) (reporting that in a national survey asking people the extent to which they approve of the Constitution that it received an average approval score of 7.8 out of 10 and a median score of 9 , whereas state constitutions received an average score of 6.7 out of 10 and a median score of 8 , and concluding that "Americans strongly back their federal Constitution"); What We Love and Hate about America, HARRIS POLL (June 8, 2010), https://theharrispoll.com/new-york-n-y-june-8-2010-a-new-harris-poll-measureswhat-americans-think-about-the-united-states-or-more-specifically-how-they-rate-16-

elements-of-american-life/ [https://perma.cc/TT5K-L5PW] (reporting that in response to the question, "How would you rate each of the following in the United States: Constitution?," $33 \%$ responded "excellent," 37\% responded "pretty good," $22 \%$ responded "only fair" and $8 \%$ responded "poor").

51. See, e.g., Stephanopoulos \& Versteeg, supra note 50, at 146-60 (reporting that respondents who self-report higher knowledge about the Constitution and who follow the news more closely are likely more supportive of the Constitution; that support for the Constitution is lower among African Americans compared to other racial groups and lower among women than among men; that support rises with education and income and is higher also among older Americans than among younger Americans; and that Republicans rate the Constitution slightly higher than do Democrats).

52. See, e.g., Pew Rsch. Ctr., Majority of Americans Say the Country 'Can Always Find Ways to Solve Our Problems' (Sept. 14, 2020), https://www.pewresearch.org/politics/2020/09/14/americans-views-of-government-lowtrust-but-some-positive-performance-ratings/pp_09-14-20_views-of-government-00-2/ [https://perma.cc/QP9M-83VW] (reporting that 57\% of respondents agree that "as 
faith in their [national] government, yet they revere the constitution that established their government and continues to structure its operations." ${ }^{53}$

\section{ii. Continued Trust in State and Local Government}

A different picture of trust in government emerges when we turn from the institutions of the federal government to state and local government. Levels of trust in state and local government have remained high over time even as trust in the national government has plummeted. ${ }^{54}$ As to state government, $60 \%$ of Americans in 2020 expressed trust and confidence in their own state governments to handle state problems; in 1972 the figure was $63 \% .{ }^{55}$ And for local government, trust has increased over time: in $1972,63 \%$ of Americans expressed trust and confidence in their local governments; in 2020, the figure was $71 \%,{ }^{56}$ meaning that trust in local government was even higher than was trust in the federal judicial branch. ${ }^{57}$ So, too, recent surveys show that on economic issues, Americans trust their state governors at significantly higher rates than they trust executive officials or congressional leaders. ${ }^{58}$ Differences in views towards the federal

Americans, we can always find ways to solve our problems and get what we want"); Pew Rsch. Ctr., Public Trust in Government Remains Near Historic Lows as Partisan Attitudes Shift (May 3, 2017), https://www.pewresearch.org/politics/2017/05/03/public-trust-ingovernment-remains-near-historic-lows-as-partisan-attitudes-shift/

[https://perma.cc/5FNN-ZR3C] (reporting that $71 \%$ of respondents expressed confidence in the future of the country).

53. Sotirios A. BARBER, CONSTITUTIONAL FAILURE 1 (2014).

54. On trust in state and local government, see generally Jennifer Wolak, Why Do People Trust Their State Government? 20 ST. POL. \& POL'Y Q. 313 (2020); Lilliard E. Richardson, David M. Konisky, \& Jeffrey Milyo, Public Approval of U.S. State Legislatures. 37 LEGIS. STUD. Q. 99 (2012); Aaron C. Weinschenk \& David J. Helpap, Political Trust in the American States, 47 ST. \& LoC. Gov'T. REV. 26 (2015); Jennifer Wolak \& Christine Kelleher Palus, The Dynamics of Public Confidence in U.S. State and Local Government, 10 ST. POL. \& POL'Y. Q. 421 (2010).

55. Gallup, Trust in Government, supra note 24.

56. Id.

57. Saad, Trust in Federal Government, supra note 42; see also Justin McCarthy, Americans Still More Trusting of Local Than State Government, GALluP (Oct. 8, 2018), https://news.Gallup.com/poll/243563/americans-trusting-local-state-government.aspx [https://perma.cc/6KPX-CPS2] (reporting that "Americans continue the decade-long trend of being more trusting of their local government than of their state government" with $72 \%$ of respondents expressing a great deal or fair amount of confidence in local government and $63 \%$ in state government).

58. Justin McCarthy, Americans Trust Governors Most Among Economic Players, GALLUP (Apr. 23, 2020), https://news.Gallup.com/poll/309173/americans-trust-governorsamong-economic-players.aspx [https://perma.cc/YQ6D-GKTN] (reporting Gallup poll 
government and state/local government help explain another survey finding: as to the people in government, in $2020,45 \%$ of Americans had a "great deal" or a "fair amount" of trust and confidence in the individuals who hold public office or are running for office; in 1972, that figure was $65 \% .^{59}$ Summarizing historical trends, researchers report that "[p]rior to declines in national government trust in the early 1970s, people often reported a preference for national government over subnational governmental units" and that "as late as 1968, survey respondents were more likely to choose the national government as the level of government that inspired the greatest confidence." 60

Historically, Gallup's national surveys did not measure levels of trust within individual states. ${ }^{61}$ Recently, however, Gallup has sought to identify variations in the degree to which residents of different states trust their own state governments. Those surveys demonstrate that trust in state government indeed varies by state. In a 2015 study, for instance, levels of confidence in state government ranged from a high of $81 \%$ in North Dakota to a low of $25 \%$ in Illinois. ${ }^{62}$ Despite these variations, a consistent story holds: "people remain significantly more trusting of their state government than the national government." ${ }^{63}$ Thus, even the least trusted state, Illinois, garners more trust than does the national government. Researchers have identified various factors that affect the level of trust a state's residents have in state and local governments. ${ }^{64}$

result that $68 \%$ of Americans say they have "a great deal" or a "fair amount" of confidence in their state governor to make economic recommendations).

59. Gallup, Trust in Government, supra note 24.

60. Wolak \& Kelleher Palus, supra note 54 at 422-23.

61. Jeffrey M. Jones, Illinois Residents Least Trusting of Their State Government, GALLUP (Apr. 4, 2014), https://news.Gallup.com/poll/168251/illinois-residents-leasttrusting-state-government.aspx [https://perma.cc/25LT-3RKR] (describing Gallup's methodology).

62. Jeffrey M. Jones, Illinois Residents Least Confident in Their State Government, GALLUP (Feb. 17, 2016), https://news.Gallup.com/poll/189281/illinois-residents-leastconfident-state-government.aspx [https://perma.cc/58Q3-WCZF].

63. Wolak, supra note 54; see also Tyler Schario \& David Konisky, Public Confidence in Government: Trust and Responsiveness, UNIV. MO. INST. PUB. POL'Y (Report 9-2008) (June 2008), https://mospace.umsystem.edu/xmlui/bitstream/ handle/10355/2545/PublicConfidenceGovernment.pdf?sequence=1\&isAllowed=y

[https://perma.cc/43BT-QK4P] (reporting that $45 \%$ of respondents agreed that the federal government can "hardly ever be trusted" but only $30 \%$ of respondents thought the same thing of state government and $25 \%$ thought it of local government).

64. See Wolak, supra note 54 (exploring how trust in state government reflects the size of state government and the accessibility of state representatives rather than 
High levels of trust in state and local government also cross party lines. While Republicans tend to have higher levels of trust in state and local government than do Democrats, the differences are quite small. "Since 2001 ... Republicans (66\%) have had higher confidence in state government than Democrats (60\%)" ${ }^{65}$ and "[o]n average since 2001, 74\% of Republicans have had confidence in local government compared with $70 \%$ of Democrats and $68 \%$ of independents. ${ }^{\circ 66}$ In 2018, a year in which Republicans controlled all three branches of the federal government, $78 \%$ of Democrats expressed confidence in local government (among Republicans the figure was 74\%); 67\% of Democrats expressed trust in state government (among Republicans the figure was $66 \%) .{ }^{67}$ In 2020 , Republicans expressed trust in state government at a rate of $56 \%$ and in local government at a rate of $69 \%$; for Democrats, the numbers were $69 \%$ and $79 \%$ respectively. ${ }^{68}$ At the same time, with respect to individual states, trust in state government tends to be higher in smaller states, which often lean Republican, than in the larger (and typically Democratic leaning) states. ${ }^{69}$

Part III will take up how these developments bear on the nature and scope of judicial review and Ely's own approach. Before turning to those issues, it is useful to provide a brief discussion of social (as distinct from political) trust and how it has changed since the era of the Warren Court.

\section{B. SOCIAL TRUST}

While political trust is trust in government, social trust refers to our trust in each other: the degree to which we believe other people to be honest and reliable and to act with integrity. Importantly, social trust captures our views not towards people we know well but towards strangers. "Social trust is trust that is mass and mutual: it is placed by almost all community members in all or almost all community members." ${ }^{\text {"T }}$ Surveys that seek to

government performance); Wolak \& Kelleher Palus, supra note 54 (reporting on how quality of life and government performance affect levels of trust in state and local government).

65. McCarthy, supra note 54 .

66. $I d$.

67. Id.

68. Saad, supra note 42.

69. Jones, supra note 62.

70. VALLIER, supra note 10 , at 49. 
gauge levels of social trust ask respondents such questions as whether or not "most people can be trusted" or instead whether "you can't be too careful in dealing with people." trust might correlate with levels of political trust. ${ }^{72}$ But political trust and social trust are different concepts: we might readily trust each other but nonetheless be highly distrustful of government.

Social trust has declined since the Warren Court era. While different surveys report different figures, "[t]he best evidence suggests that social trust rose from the mid-1940s to the mid1960s, peaking in 1964.... In the mid-1960s, however, this beneficent trend was reversed, initiating a long-term decline in social trust." ${ }^{73}$ For instance, since 1972, the General Social Survey has asked respondents: "Generally speaking, would you say that most people can be trusted or that you can't be too careful in dealing with people?"74 Possible responses are: "Can trust," "Cannot trust," "Depends," "Don't Know," and "Not Applicable." In 1972, the proportion of respondents answering "Can trust" was $46 \%$. In 2018, the proportion was $21 \% .{ }^{75}$ The American National Election Studies survey reports that $55 \%$ of respondents in 1964 expressed trust towards others, a drop to $46 \%$ in 1972 and then a further drop to below $30 \%$ in 2008 (since then ANES has used a five-point scale that also demonstrates low current levels of social trust) ${ }^{76}$ Significantly, "[m]ost ... of the decline in American social trust since the 1960s is attributable to generational succession." 77 Each generation of Americans is less trusting than the one that preceded it even though an individual's own level of social trust does not change much during his or her

71. Robert D. Putnam, Bowling Alone: The Collapse and Revival of AMERICAN COMMUNITY 137 (2000).

72. See Bo Rothstein \& Dietlend Stolle, The State and Social Capital: An Institutional Theory of Generalized Trust, 40 COMPAR. POL. 441, 450 (2008), https://www.jstor.org/stable/20434095 [https://perma.cc/4ATW-8EMD] (reporting a "strong relationship" between "order institutions" such as the police and courts and social trust).

73. PUTNAM, supra note 71 at $139-40$.

74. GSS Data Explorer, Can People Be Trusted, NORC U. Chi., https://gssdataexplorer.norc.org/variables/441/vshow [https://perma.cc/UJP6-4ZFM] (last visited Nov. 1, 2021).

75. Id.

76. American National Election Studies, ANES Time Series: 1964 Time Series Study (May 3, 1999), https://electionstudies.org/data-center/1964-time-series-study/ [https://perma.cc/6S6G-P4DA].

77. PUTNAM, supra note 71, at 140. 
lifetime. ${ }^{78}$ Thus, a recent Pew poll reports that $19 \%$ of Americans over 65 said most people cannot be trusted but $46 \%$ of Americans aged 18-29 took that view. ${ }^{79}$

Social distrust has also hardened along political lines: Americans have become even less trusting of those with different political beliefs or affiliations, resulting in well-documented increases in partisanship. ${ }^{80}$ Social scientists who analyze political polarization often trace the rise in modern partisanship to 1968, with the Southern realignment, in which Southern White voters shifted from the Democratic to the Republican party and propelled Richard Nixon to the White House in the 1972 presidential election. ${ }^{81}$ Consistent with this trend, political partisanship has weakened our willingness to trust those whose politics differ. In 2017, 70\% of Democrats said voters for Donald Trump could not be trusted; Republicans in similar numbers said the same of voters for Hillary Clinton. ${ }^{82}$ Indeed, since the time of the Warren Court, Americans are not just less trusting - they are

78. Id. at 140-41. See also Robert V. Robinson \& Elton F. Jackson, Is Trust in Others Declining in America? An Age-Period-Cohort Analysis, 30 Soc. SCI. RsCH. 117 (2001) (reporting both generational declines in trust and some contrary life cycle effects).

79. Pew Rsch. Ctr., Trust and Distrust in America (July 22, 2019), https://www.pewresearch.org/politics/2019/07/22/trust-and-distrust-in-america/ [https://perma.cc/WK3P-N8EC].

80. See, e.g., Robert D. PUtnam, The Upswing: How AMERICA CAME Together a Century AGo ANd How We CAN Do It Again 70-71 (2020) (reporting on how "[t]he last five decades of steadily accelerating partisanship have produced the deeply polarized world in which we live today."); Alan Abramowitz \& Steven W. Webster, Negative Partisanship: Why Americans Dislike Parties But Behave Like Rabid Partisans, 39 ADVANCES POL. PSYCH. 119 (2018) (tracing the rise in "negative partisanship," i.e., alignment against one political party, and its effects); Levi Boxell et al., Cross-Country Trends in Affective Polarization (NBER Working Paper 2020), https://www.brown.edu/Research/Shapiro/pdfs/cross-polar.pdf [https://perma.cc/R5FNNKKU] (reporting that over the past four decades, among nine OECD countries, the U.S. experienced the largest increases in affective polarization, the degree to which individuals view other political parties negatively); Shanto Iyengar \& Masha Krupenkin, The Strengthening of Partisan Affect, 39 ADVANCES POL. PsYCH. 201 (2018) (reporting on the rise in partisan animus since the 1980s and its impact on voter turnout); Philip Edward Jones, Partisanship, Political Awareness, and Retrospective Evaluations, 1956-2016, 42 POL. BEH. 1295 (2020) (reporting on increases in partisan differences in evaluations of objective conditions).

81. See, e.g., Alan Abramowitz \& Jennifer McCoy, United States: Racial Resentment, Negative Partisanship, and Polarization in Trump's America, 681 ANNALS AM. ACAD. OF POL. \& SOC. SCI., 137, 138 (2018) ("[T]he Southern Democratic political party realignment in the 1970 s and 1980s led to increased party polarization in the 1990s and 2000s as Americans sorted into more ideologically homogeneous political parties, perceived the parties as growing further apart on policies, and their representatives in Congress voted in more lock-step party unity roll-call votes.").

82. VALLIER, supra note 10, at 1. 
also more hateful. In the 1980s, only small numbers of voters (10$20 \%$ ) said they actually hated members of the other political party but since 2000, half of voters express hatred towards their political opponents. ${ }^{83}$ Declining social trust also means declining respect for the political judgments of fellow citizens. In 1972, 83\% of Americans had "a great deal" or "a fair amount" of trust and confidence in "the American people as a whole when it comes to making judgments under our democratic system about the issues facing our country;" in 2020, the figure was 56\%. ${ }^{84}$

The remainder of this Essay explores how changes in political and social trust since the Warren Court era inform the role of courts in performing judicial review.

\section{POLITICAL TRUST AND JUDICIAL REVIEW}

This Part considers how changes in levels of political trust, particularly the remarkable decline in the public's trust in the federal government since the Warren Court era, should influence the way in which we think about the nature and scope of judicial review and the continued relevance of Ely's approach.

One possible assessment is that changes in political trust have no relevance to the role of courts that Ely defends. On this view, whether political processes are or are not deserving of trust does not depend upon how much trust or confidence members of the general public actually have in government. Thus, public perceptions of trust are not necessarily good evidence of trustworthiness in the Elyan sense-not a relevant basis for assessing whether political channels are sufficiently open to allow for change and that the interests of minorities are adequately protected in the political process. Members of the public who express trust in government might not have thought about those issues or considered them significant to themselves in deciding whether government is trustworthy. Indeed, high levels of trust on the part of a public majority might, from an Elyan perspective, raise suspicion: the majority of the public might trust government precisely because it works to protect the majority, delivers benefits to the majority, and takes little or no account of minoritarian interests - and for these very reasons, the majority might be content with channels of change being closed off or

83. Id., at $1-2$.

84. Gallup, Trust in Government, supra note 24. 
difficult to access. Majoritarian trust in government, then, is not just unhelpful to discerning trustworthiness, in an Elyan sense, but, if it plays any role it should trigger skepticism towards governmental operations. Judicial review should, then, operate today in just the same way Ely proposed four decades ago.

On the other hand, there are some plausible reasons for concluding that levels of public trust in government should, at least in some circumstances, inform how courts engage in judicial review. First, public perceptions of trustworthiness might be based upon the very factors of interest to Ely-whether government is responsive to its electorate and takes account of the full range of positions and interests or instead suffers from corruption and works to entrench itself from reform-and the public might be in a good position to observe and report on those factors. Second, taking account of the extent to which the public has trust or confidence in governmental institutions might allow for a more tailored and dynamic approach to judicial review than does Ely's approach by itself. As explored below, attention to public trust could permit the extent and circumstances of judicial review to vary by jurisdiction and vary also across different governmental institutions and actors; the nature and scope of judicial review might also vary over time as levels of trust rise or fall. Third, judicial review might appear more legitimate if it is attentive to levels of public trust by, for example, correcting failures in the political process that the public itself recognizes. Fourth, if judicial review tracks public distrust, review itself might serve as an effective tool for reforming process failures: reports of public levels of trust can identify where failures exist and bring attention to them to allow for strategic deployment of judicial resources. Fifth, even if high public trust should not relax judicial scrutiny (and, might arguably be a basis for even closer judicial review), high levels of distrust could nonetheless signal a need for enhanced judicial review: if the public doesn't trust certain institutions of government, that itself is at least some indication of process problems of the kind that concern Ely. In sum, there is a case to be made that judicial review can helpfully track or be responsive to political (dis)trust, with courts more inclined to intervene when citizens distrust government, and to intervene particularly with respect to the governmental institutions that generate low levels of popular confidence. The approach would have a series of implications. The remainder of this Part sketches 
some potential implications for (A) judicial scrutiny of federal versus state or local laws; (B) inquiries into governmental motives; (C) the scope of congressional power, particularly in close federalism cases; (D) federal regulation of state voting processes; (E) the Court's anti-commandeering doctrine; and $(\mathrm{F})$ uniform applications of federal constitutional rights. The goal is breadth rather than depth: I offer some brief observations on each point as a basis for future conversation rather than as the final word.

\section{A. DIFFERENTIAL SCRUTINY}

At a most general level, changes in allocations of political trust suggest that today the Supreme Court should be inclined to scrutinize federal law and federal executive actions more frequently and more rigorously than it reviews state and (especially) local government laws and actions - which would, therefore, receive greater deference.

Here, we can usefully draw some contrasts with the work of the Warren Court. The Warren Court will be remembered for its aggressive approach to protecting individual rights. But that characterization misses a good part of the story. The Warren Court's rights jurisprudence mostly involved claims against state and local government - with relatively few cases in which federal governmental action was under review. The caselaw of the Warren Court construing and enforcing the provisions of the Bill of Rights centered around claims against state and local governments - even as those decisions had, in turn, implications also for federal action-such that the robustness of the Bill of Rights protections today traces to their application to states and localities. ${ }^{85}$ So, too, the Warren Court's rulings on suspect

85. See, e.g., NAACP v. Ala. ex rel. Patterson, 357 U.S. 449 (1958) (compelled disclosure of organizational membership list violates First Amendment); Torcaso v. Watkins, 367 U.S. 488 (1961) (First Amendment bars religious tests for public office); Engel v. Vitale, 370 U.S. 421 (1962) (requirement to recite government-written prayer in public schools violates First Amendment's Establishment Clause); Gideon v. Wainwright, 372 U.S. 335 (1963) (Sixth Amendment requires government to provide criminal defendants with appointed counsel); Brady v. Maryland, 373 U.S. 83 (1963) (due process requires government to disclose exculpatory evidence in criminal cases); New York Times Co. v. Sullivan, 376 U.S. 254 (1964) (absent a showing of actual malice, First Amendment bars defamation lawsuits by public officials); Escobedo v. Illinois, 378 U.S. 478 (1964) (Sixth Amendment protects right to counsel during police interrogations); Beck v. Ohio, 379 U.S. 89 (1964) (if arrest not supported by probable cause incident search violates Fourth Amendment); Griffin v. California, 380 U.S. 609 (1965) (Fifth Amendment 
classifications and heightened review developed principally from cases brought against state and local governmental actors under the Fourteenth Amendment's Equal Protection Clause-with, then, a feedback effect upon the federal government as a matter of Fifth Amendment Due Process. Most obviously, there would have been no Bolling v. Sharpe ${ }^{86}$ without Brown v. Board of Education. ${ }^{87}$ In addition, in the area of voting rights, the Warren Court's cases involving particular state and local governments established important principles that bind other states and localities and also the national government. ${ }^{88}$ Finally, for better or for worse, the Warren Court's recognition of implied constitutional rights, as a matter of substantive due process or on other grounds, came largely in cases, such as Griswold v. Connecticut ${ }^{89}$ also involving state and local laws and regulations. The nature of public trust today arguably points to a different orientation, one in which courts look with greater suspicion at federal laws and federal executive action, and compared to the approach of the Warren Court, leave states and localities relatively alone.

\section{B. GOVERNMENTAL MOTIVE}

Attention to political trust can also inform the role of courts in evaluating governmental motive. Ely himself identifies impermissible motive-particularly prejudice-as a failure of representation and, in his account, the basis for judicial invalidation of what the government has done. While recognizing that proving illicit governmental motive is often difficult, ${ }^{90}$ Ely

prohibits prosecutor from commenting on defendant's refusal to testify); Miranda v. Arizona, 384 U.S. 436 (1966) (Fifth Amendment prohibits use of statements made in police custody absent warning of and voluntary waiver of right to counsel and to remain silent); Schmerber v. California, 384 U.S. 757 (1966) (absent exigent circumstances, Fourth Amendment requires warrant before taking blood sample from suspect); Stanley v. Georgia, 394 U.S. 557 (1969) (First Amendment protects private possession of obscene materials); Brandenburg v. Ohio, 395 U.S. 444 (1969) (First Amendment prohibits government from punishing inflammatory speech unless directed to inciting or producing imminent lawless action and likely to incite or produce such action).

86. 347 U.S. 497 (1954).

87. 347 U.S. 483 (1954)

88. See, e.g., Gomillion v. Lightfoot, 364 U.S. 339 (1960) (finding an electoral district created to disenfranchise Black voters violates the Fifteenth Amendment); Gray v. Sanders, 372 U.S. 368 (1963) (adopting the "one person, one vote" standard for legislative districting under the Fourteenth Amendment).

89. 381 U.S. 479 (1965).

90. ELY, supra note 2, at 137. 
writes that "[it] is inconsistent with constitutional norms to select people for unusual deprivation on the basis of race, religion, or politics, or even simply because the official doing the choosing doesn't like them" and thus "[w]hen such a principle of selection has been employed, the system has malfunctioned," 91 thereby warranting judicial intervention. Differential levels of public trust in government can guide a court's inclination to scrutinize motive, and, in performing such scrutiny, its granting or withholding of benefits of doubts.

Consider two recent cases in which motive was at issue. In June of 2018 the Supreme Court decided two cases involving claims of government action impermissibly motivated by religious bias. In the Masterpiece Cakeshop case, the Court held that the Colorado Civil Rights Commission's application of the state's non-discrimination law against a bakery owner who refused to create a cake for a same-sex wedding was motivated by hostility towards religion and thus violated the First Amendment. ${ }^{92}$ On the other hand, in Trump v. Hawaii, ${ }^{93}$ the Court rejected a challenge to President Trump's executive order banning entry of certain non-citizens from designated countries as involving animus towards Muslims.

In Masterpiece Cakeshop, citing statements made by the commission's members and the commission's differential actions in other cases, the Court reasoned that the First Amendment "bars even 'subtle departures from neutrality' on matters of religion." 94 In Hawaii, however, the Court, rejecting the plaintiffs' claim that seemingly anti-Muslim statements by Trump rendered the travel ban invalid, emphasized that given the "delicate issues" involved, concluded that "because there is persuasive evidence that the entry suspension has a legitimate grounding in national security concerns, quite apart from any religious hostility, we must accept that independent justification"96 and it would not further "probe the sincerity" of that justification "by reference to extrinsic statements." 97

91. Id. at 137 (footnote omitted). (2018).

92. Masterpiece Cakeshop, Ltd. v. Colorado Civil Rights Comm'n, 138 S. Ct. 1719

93. 138 S. Ct. 2392 (2018).

94. 138 S. Ct. at 1731 (internal citation omitted).

95. Hawaii, 138 S. Ct. at 2418.

96. Id. at 2421.

97. Id. at 2418 . 
Context, of course, matters: admission of non-citizens (particularly when national security concerns are raised) presents different questions from regulation of a commercial entity such as a bakery. At the same time, levels of public trust today suggest that the Court should have been more deferential than it was to state government in Masterpiece Cakeshop and less deferential than it was to the President in Hawaii.

Consider also a pair of cases involving same-sex marriage in which the Court invalidated laws on the ground that their only basis was irrational prejudice: United States v. Windsor, invalidating section 3 of the federal Defense of Marriage Act, which amended the Dictionary Act to define "marriage" and "spouse" for federal purposes as excluding same-sex partners, ${ }^{98}$ and Obergefell v. Hodges, which invalidated state laws refusing recognition of same-sex marriages..$^{99}$ In dissents in Windsor, Chief Justice Roberts and Justice Scalia complained that the majority was wrong to attribute animus to the federal political branches. ${ }^{100}$ But attention to the dynamics of political trust suggests that the Court was on solid ground in its skepticism that DOMA was not motivated by an illicit purpose. On the other hand, from a political trust perspective, the Court's approach in Obergefell seems less defensible, with the Court wrong to apply its same prejudicebased assessment from Windsor to the state laws in Obergefell, or at least wrong in failing to give the states in Obergefell greater benefit of the doubt than the Windsor Court allowed Congress and the President.

98. See United States v. Windsor, 570 U.S. 744, 775 (2013) ("The federal statute is invalid, for no legitimate purpose overcomes the purpose and effect to disparage and to injure those whom the State, by its marriage laws, sought to protect in personhood and dignity.").

99. See Obergefell v. Hodges, 576 U.S. 644, 675 (2015) ("Especially against a long history of disapproval of their relationships, this denial to same-sex couples of the right to marry works a grave and continuing harm. The imposition of this disability on gays and lesbians serves to disrespect and subordinate them.").

100. See Windsor, 570 U.S. at 776 (Roberts, C.J., dissenting) ("At least without some more convincing evidence that the Act's principal purpose was to codify malice, and that it furthered no legitimate government interests, I would not tar the political branches with the brush of bigotry."); id. at 795-96 (Scalia, J., dissenting) ("[T]he object of this condemnation is not the legislature of some once-Confederate Southern state . . but our respected coordinate branches, the Congress and Presidency of the United States. Laying such a charge against them should require the most extraordinary evidence, and I would have thought that every attempt would be made to indulge a more anodyne explanation for the statute."). 


\section{Congressional Power}

Levels of political trust, and their changes over time, can also usefully inform federalism analysis - an issue that Ely does not consider in any depth. In a very general sense, the increased public distrust towards Congress might mean "we cannot trust the insiders in Congress to be the judges of the scope of their own power" 101 and thus courts should play an especially active role in policing federalism boundaries. Public distrust of the federal government should, then, weigh against reliance on political safeguards of federalism ${ }^{102}$ and point instead to a robust role for courts in preventing federal overreaching.

In addition, allocations of public trust today suggest that courts, perhaps, even if only at the margins, should resolve federalism disputes in favor of state (and local) government power, as to which political trust far outweighs that placed in the national government, in ways that favor governmental decisions and actions by institutions that enjoy higher public confidence. On this approach, the Warren Court's broad conception of federal power-during a period of high trust in the federal governmentin cases such as Heart of Atlanta ${ }^{103}$ and McClung, ${ }^{104}$ was appropriate. But appropriate, too, were the decisions by the Rehnquist Court-at a time of reduced trust in Congresslimiting federal power, in cases such as Lopez ${ }^{105}$ and Morrison. ${ }^{106}$

101. Steven G. Calabresi, The Constitution and Disdain, 126 HARV. L. REV. F. 13, 17 (2012).

102. See Garcia v. San Antonio Metro. Transit Auth., 469 U.S. 528, 551 (1985) (invoking "[t]he effectiveness of the federal political process in preserving the States' interests" in rejecting metropolitan transit authority's federalism challenge to application of minimum wage and overtime pay provisions of federal Fair Labor Standards Act).

103. Heart of Atlanta Motel v. United States, 379 U.S. 241 (1964) (holding, in a challenge brought by a motel operator, public accommodations provisions of the Civil Rights Act of 1964 valid under the Commerce Clause).

104. Katzenbach v. McClung, 379 U.S. 294 (1964) (holding public accommodations provisions of the Civil Rights Act of 1964 valid, under the Commerce Clause, as applied to a restaurant).

105. United States v. Lopez, 514 U.S. 549, 551 (1995) (invalidating, as beyond congressional power under the Commerce Clause, the Federal Gun-Free School Zones Act of 1990, which criminalized possession of guns within one thousand feet of a school). See generally Jason Mazzone \& Carl Emery Woock, Federalism as Docket Control, 94 N.C. L. REV. 7 (2015) (discussing the Rehnquist Court's "federalism revolution.").

106. United States v. Morrison, 529 U.S. 598, 627 (2000) (invalidating the civil remedy provision of the federal Violence Against Women Act as supported neither by the Commerce Clause nor by Section 5 of the Fourteenth Amendment). 


\section{Federal Regulation of State Election Processes}

Shifts, since the time of the Warren Court, in allocations of public trust can also inform assessments of federal regulation of state electoral processes. In particular, the decline in public trust in Congress and the federal executive branch supports a more skeptical approach to federal interventions into state electoral practices than was appropriate during the Warren Court era.

As one example in this area, a political trust account lends support to the Court's rulings, on challenged provisions of the federal Voting Rights Act (VRA), in South Carolina $v$. Katzenbach in 1965 as well as in Shelby County v. Holder in 2013. ${ }^{107}$ Katzenbach rejected the challenge and upheld the VRA provisions; Shelby County reached the opposite result. Both decisions make considerable sense from a political trust perspective.

Consider, first, Katzenbach. As key elements of a unique approach to curing discriminatory voting practices, Section 4 of the 1965 VRA adopted a formula to identify "covered" jurisdictions ${ }^{108}$ that were then subject to federal pre-clearance requirements and other restrictions under Section 5 of the Act. ${ }^{109}$ Under Section 4's formula, a state or locality was covered if it used any test or device as a condition for voter registration on November 1, 1964, and either less than 50 percent of voting age persons were registered to vote on that date or less than 50 percent voted in the presidential election that year. ${ }^{110}$ As a result of this formula, in 1965 six states in their entirety became covered jurisdictions-Alabama, Georgia, Louisiana, Mississippi, South Carolina, and Virginia - along with thirty-nine counties in North Carolina and one county in Arizona. ${ }^{111}$ Section 4 banned all tests or devices in these covered jurisdictions ${ }^{112}$ and under Section 5, changes in voting procedures could not take effect in a covered jurisdiction unless first approved by either the Attorney General or a three-judge district court in Washington, DC, and only then if the jurisdiction demonstrated that the proposed change in

107. South Carolina v. Katzenbach, 383 U.S. 301 (1966); Shelby County v. Holder, 570 U.S. 529 (2013).

108. Voting Rights Act of 1965, Pub. L. No. 89-110 § 4, 79 Stat. 437, 438-39 (codified as amended in scattered sections of 42 and 52 U.S.C.).

109. Id. \$ 5, 79 Stat. at 439 .

110. Id. § 4(b), 79 Stat. at 438 .

111. 28 C.F.R. pt. 51, app. (2015)

112. Voting Rights Act $\S 4(a)$ of $1965 \S 4(a), 79$ Stat. at 438. 
voting procedures had neither "the purpose nor ... the effect of denying or abridging the right to vote on account of race or color." 113

In Katzenbach, the Court, in an opinion by Chief Justice Warren, rejected arguments by South Carolina that the VRA exceeded Congress's Fifteenth Amendment enforcement power. Taking a broad view of Congress's authority and a modest view of the Court's own role of review, Warren wrote: "[T]he Fifteenth Amendment, the prior decisions construing its several provisions, and the general doctrines of constitutional interpretation, all point to one fundamental principle. As against the reserved powers of the States, Congress may use any rational means to effectuate the constitutional prohibition of racial discrimination in voting." 114 Under that approach, the coverage formula easily survived: "Tests and devices are relevant to voting discrimination because of their long history as a tool for perpetrating the evil; a low voting rate is pertinent for the obvious reason that widespread disenfranchisement must inevitably affect the number of actual voters." $" 115$ And federal pre-clearance of new election procedures in covered jurisdictions was appropriate, given that "Congress had reason to suppose that ... States might try ... to evade the remedies for voting discrimination contained in the Act itself." 116

The decision in Katzenbach reflected a high level of confidence that congressional intervention in state political processes involved a necessary response to an identified denial of voting rights. Over and over, Warren's opinion flagged the trustworthiness of the federal political process. Congress, Warren wrote, had "explored with great care the problem of racial discrimination in voting" and, as evidenced by the decisive vote in favor of the bill, "the verdict of both chambers was overwhelming." "117 The Court noted two lessons from the extensive congressional debates and record: that "Congress felt itself confronted by an insidious and pervasive evil which had been perpetuated in certain parts of our country through unremitting and ingenious defiance of the Constitution" and that "Congress concluded that the unsuccessful remedies which it had

113. Id. $\S 5,79$ Stat. at 439 .

114. South Carolina v. Katzenbach, 383 U.S. 324 (1966).

115. Id. at 330 .

116. Id. at 335

117. Id. at 308-09. 
prescribed in the past would have to be replaced by sterner and more elaborate measures in order to satisfy the clear commands of the Fifteenth Amendment." 118

As originally enacted, the VRA was set to expire in five years. However, Congress extended the statute-with certain updates and amendments-five times, most recently with a twenty-five-year extension in 2006. ${ }^{119}$ Significantly, in 2006 Congress did not update the coverage formula but rather kept in place determinations based upon voting data from the 1960s and early 1970s. At the time of the 2006 reauthorization, nine states were deemed covered jurisdictions in their entirety (Alabama, Alaska, Arizona, Georgia, Louisiana, Mississippi, South Carolina, Texas, and Virginia), and six other states were covered in part (California, Florida, Michigan, New York, North Carolina, and South Dakota). ${ }^{120}$

In Shelby County, the Court held that the coverage formula of Section 4 of the VRA, as extended in 2006, was now unconstitutional as beyond the scope of congressional power under Section 2 of the Fifteenth Amendment. ${ }^{121}$ The coverage formula therefore violated the Tenth Amendment. ${ }^{122}$ The core of the problem, according to Chief Justice Roberts in his opinion for the Court, was that the formula-based on data from the 1960s and 1970s-could not be justified "in light of current conditions." ${ }^{23}$ Despite improvements in registration and voting (that had occurred largely as a result of the VRA itself), Congress had not "eased the restrictions in [Section] 5 or narrowed the scope of the coverage formula in [Section] 4(b)" 124 and thus the VRA's cure was no longer "sufficiently related to the problem that it targets." 125

Whereas in Katzenbach, Warren had confidence in the Congress that produced the 1965 VRA, for Roberts in Shelby

118. Id. at 309

119. Fannie Lou Hamer, Rosa Parks, and Coretta Scott King Voting Rights Act Reauthorization and Amendments Act of 2006, Pub. L. No. 109-246, 120 Stat. 577.

120. See Jurisdictions Previously Covered by Section 5, U.S. DEP'T JUST. (Aug. 6, 2015), http://www.justice.gov/crt/jurisdictions-previously-covered-section-5 [https://perma.cc/DP4C-23VN].

121. Shelby County v. Holder, 570 U.S. 529, 555 (2013).

122. Id.

123. Id. at 553 .

124. Id. at 549 .

125. Id. at 551 (quoting Nw. Austin Mun. Util. Dist. No. One v. Holder, 557 U.S. 193, $203(2009))$. 
County, the 2006 extension was the product of an unreliable political process-lacking the sort of careful contemporaneous analysis of problem and solution Congress had conducted in 1964. Roberts explained that "[i]f Congress had started from scratch in 2006 , it plainly could not have enacted the present coverage formula" 126 because "[i]t would have been irrational for Congress to distinguish between States . . . based on 40-year-old data, when today's statistics tell an entirely different story" and equally "irrational to base coverage on the use of voting tests 40 years ago, when such tests have been illegal since that time."127 Additional evidence of a failed process lay in the inability of Congress to generate a new formula even after the Court, three years earlier had expressed doubts about the constitutionality of Section 5 and given Congress an opportunity to correct the problem. ${ }^{128}$ Further, the failed process in 2006 involved regulation of states and localities and limitations on their own ability to regulate elections: skepticism towards the federal government thus took on sharpened significance. ${ }^{129}$

Importantly, from a political trust perspective, in Shelby County Roberts affirmed that Congress had power to suspend state election laws and require preclearance of new state lawsbut such measures had to be justified by current conditions. ${ }^{130}$ Thus, the Court in Shelby County did not invalidate Section 5 of the VRA (although Justice Thomas would have done so) ${ }^{131}$ nor did the Court preclude Congress from adopting a new Section 4 formula to justify the continued imposition of the Section 5

126. Shelby County v. Holder, 570 U.S. 529, 556 (2013)

127. Id.

128. Id. at 540 .

129. Roberts identified three key federalism concerns. First, by treating some states less favorably than others, the VRA implicated the constitutional principle of the "equal sovereignty" of the states. Id. at 544. Of particular concern was that the VRA divided states into two groups that represented a North-South divide. While this division was once pertinent, it no longer reflected present-day conditions. Id. at 551-52. Second, "disparate treatment," under the VRA, occurred in the particular context of state lawmaking. Covered states needed federal permission before taking legislative action. Id. at 544. Third, by targeting election laws, the VRA struck at a particularly important state lawmaking power, one that lay at the heart of self-government. $I d$. Roberts concluded: "Congress - if it is to divide the States - must identify those jurisdictions to be singled out on a basis that makes sense in light of current conditions." Id. at 553.

130. Id. at 553 .

131. Shelby County v. Holder, 570 U.S. 529, 559 (2013) (Thomas, J., concurring) ("The extensive pattern of discrimination that led the Court to previously uphold $\$ 5$ as enforcing the Fifteenth Amendment no longer exists.") (internal quotation and citation omitted). 
measures. ${ }^{132}$ Shelby County also did not overrule Katzenbach and depicted the VRA, as of 1965, a proper exercise of Congress's power, even in light of the federalism issues the original law itself implicated. But a trustworthy political process in 1964 could not sustain the 2006 VRA extension. That approach reflects something obvious about political trust: even when large overall percentages of the public trust their state and local governments and distrust Congress, a minority of the public might still have little confidence in the fairness of politics at the state and local level. Federal intervention in state and local processes is thus appropriate if it tracks well-founded minoritarian distrust. Shelby County leaves open that possibility.

\section{E. FEDERAL COMMANDEERING}

The Supreme Court has held that the federal government may not commandeer state legislative or executive officials by compelling them to carry out federal programs. ${ }^{133}$ A political trust perspective buttresses that conclusion.

The Court itself has articulated a series of reasons for the anti-commandeering doctrine. In its most recent decision in this line of cases, Murphy v. National Collegiate Athletic Ass' $n,{ }^{134}$ the Court noted three justifications: First, because the anticommandeering rule protects division of governmental powers, it "serves as one of the Constitution's structural protections of liberty." 135 Second, the rule "promotes political accountability" in that "[v]oters who like or dislike the effects of the regulation know

132. Id. at 557 (majority opinion).

133. Printz v. United States, 521 U.S. 898, 935 (1997) ("Congress cannot circumvent ... [the anti-commandeering bar] by conscripting the States' officers directly. The Federal Government may neither issue directives requiring the States to address particular problems, nor command the States' officers, or those of their political subdivisions, to administer or enforce a federal regulatory program.") (invalidating provisions of the Brady Handgun Violence Prevention Act requiring local law enforcement officials to conduct background checks); New York v. United States, 505 U.S. 144, 162 (1992) ("While Congress has substantial powers to govern the Nation directly ... the Constitution has never been understood to confer upon Congress the ability to require the States to govern according to Congress' instructions.") (invalidating provisions of the federal Low-Level Radioactive Waste Policy Amendments Act requiring states to regulate low-level radioactive waste).

134. Murphy v. Nat'l Collegiate Athletic Ass'n, 138 S. Ct. 1461 (2018) (holding that provisions of Professional and Amateur Sports Protection Act making it unlawful for a state to authorize or license sports gambling violate the anticommandeering doctrine and finding remaining provisions of Act inseverable).

135. Id. at 1477 (internal quotation and citation omitted). 
who to credit or blame." 136 Third, the anti-commandeering rule requires the federal government to take account of and provide for enforcement costs rather than shifting them onto state government. ${ }^{137}$

The second of these reasons in particular reflects notions of political trust: if members of the public distrust Congress, it surely has incentives to avoid attention from and responsibility for regulatory burdens it imposes - and to make unpopular programs appear the handiwork of state government. More generally, the anti-commandeering doctrine keeps states and localities free to decide whether and when to draw on the stock of political trust they have accumulated - such that the federal government cannot itself seek to leverage (and perhaps thereby deplete) public trust in states and localities as a mechanism for effective enforcement of federal laws that might otherwise encounter resistance. Significantly, the anti-commandeering doctrine does not prevent state governments from agreeing to provide assistance to the federal government on terms and under circumstances that the state itself accepts and with respect to federal programs the state views as valuable. States, in other words, remain free to draw on their reservoirs of public confidence if they so choose, even as the federal government cannot itself tap the reservoir on its own.

\section{F. UNIFORMITY AND VARIATION IN FEDERAL CONSTITUTIONAL RIGHTS}

A political trust perspective also lends support to differential applications of federal constitutional rights today. The Warren Court was the engine that nationalized federal rights, imposing uniform requirements, particularly of the Bill of Rights, upon every state and local government. We now take for granted that federal rights must apply uniformly: that if the First Amendment protects speech in Kansas, it protects the same speech in New York; that if a Chicago ordinance violates the Fourteenth Amendment Equal Protection Clause then Houston cannot maintain an identical ordinance. Uniformity of federal rights has value: Americans need not worry about losing protections as they cross state lines and state constitutions remain a source for stronger rights beyond those the federal Constitution gives us, 
everywhere, in common. Still, as members of the Court have on occasion observed, ${ }^{138}$ there might well exist good reasons for different approaches, even to federal rights, in light of differences among states and localities. For instance, a stronger version of Fourth Amendment restrictions in states and localities with a long history of abusive police conduct and accompanying distrust and fear of law enforcement might be a more sensible strategy than a one-size-fits-all approach. Likewise, when Americans trust their state and local governments far more than they trust the federal government, courts should consider applying stronger versions of federal rights when reviewing federal laws and actions than in cases involving claims against states or localities. In these ways, attention to differences in political trust can help tailor federal rights.

\section{SOCIAL TRUST AND JUDICIAL REVIEW}

As discussed in Part I, levels of social trust have also declined since the Warren Court era. This final Part sketches how those declines might inform approaches to judicial review.

One approach is that low levels of social trust caution against the Court seeking to issue definitive resolutions of contested social and political questions. On this view, judicial decisions aimed at settling contested issues are not likely to overcome social distrust and might well exacerbate it - and there might be costs to the Court itself if it appears to have been captured by one side or

138. See, e.g., Kansas v. Carr, 136 S. Ct. 633, 646 (2016) (Sotomayor, J., dissenting) (dissenting from the Court's reversal of the Kansas Supreme Court's decision vacating death sentences imposed upon three defendants on the ground that the jury sentencing instructions violated the Eighth Amendment for failing to affirmatively inform the jury that mitigating circumstances need only be proved to the satisfaction of the individual juror in that juror's sentencing decision and not beyond a reasonable doubt, and explaining that the Court had "no reason to intervene in cases like these - and plenty of reasons not to" in instances where a state has "not violated any federal constitutional right" and merely "overprotected its citizens based on its interpretation of state and federal law."); McDonald v. Chicago, 561 U.S. 742, 912 (2010) (Breyer, J., dissenting) (dissenting from the Court's incorporation of the Second Amendment and arguing in favor of differences among states and localities with respect to the scope of gun possession rights in light of differences of population density, patterns of gun violence, and other factors); California v. Ramos, 463 U.S. 992, 1031 (1983) (Stevens, J., dissenting) (dissenting from the Court's reversal of a decision by the California Supreme Court that in capital cases the Eighth Amendment prohibits instructing the sentencing jury that it may take into account the governor's power to commute a life sentence, and explaining that an application of the Eighth Amendment to favor a defendant was "plainly a matter that is best left to the States"). 
another in a political dispute. Members of the Court have themselves articulated these concerns in different cases. One example comes from the dissenting Justices in the series of cases, beginning with Romer v. Evans, ${ }^{139}$ involving classifications based on sexual orientation. "The Court," wrote Justice Scalia in his dissenting opinion in Romer v. Evans, "has mistaken a Kulturkampf for a fit of spite." 140 Scalia's point was that in holding Amendment 2 of the Colorado Constitution-which imposed a state-wide ban on governmental measures barring sexual orientation discrimination - was an animus-based classification in violation of the Equal Protection Clause, the majority had taken sides in a cultural war that was better left to political and social processes to resolve. Given the ensuing successes of the gay rights movement, the particular issue in Romer today easily seems of another age. In 1996, the year the Court decided Romer, Bowers v. Hardwick, ${ }^{141}$ which had rejected a constitutional challenge to laws criminalizing same-sex intimate conduct, was good law; Bowers would not be overturned for another seven years. ${ }^{142}$ And in 1996 the prospect of federal constitutional protection for samesex marriage was sufficiently remote that Scalia's Romer dissent, though it flagged other ways in which the Court majority had upset traditional mores, made no prediction that marriage laws would also soon fall. When, in 2015, the Court in Obergefell $v$. Hodges $^{143}$ held unconstitutional state-law refusals to license samesex marriages, Scalia again complained that the majority had unwisely injected itself into an ongoing political and social process. This time, though, Scalia spoke not of cultural warfare but of dialog and persuasion. "Until the courts put a stop to it," Scalia wrote in Obergefell, "public debate over same-sex marriage displayed American democracy at its best. Individuals on both sides of the issue passionately, but respectfully, attempted to persuade their fellow citizens to accept their views." 144 The Chief Justice (also in dissent) predicted some broader implications. "Closing debate tends to close minds," Roberts warned, and "[p]eople denied a voice are less likely to accept the ruling of a court on an issue that does not seem to be the sort of thing courts

139. 517 U.S. 620 (1996) (invalidating Amendment 2 of the Colorado Constitution).

140. Id. at 636 (Scalia, J., dissenting).

141. Bowers v. Hardwick, 478 U.S. 186 (1986).

142. Lawrence v. Texas, 539 U.S. 558 (2003) (overruling Bowers).

143. 576 U.S. $644(2015)$.

144. Id. at 714 (Scalia, J., dissenting). 
usually decide." 145 The consequence: "[s]tealing this issue from the people will for many cast a cloud over same-sex marriage, making a dramatic social change that much more difficult to accept." 146 Roberts cited Democracy and Distrust for the proposition that judges announcing implied constitutional rights are just imposing their own preferences. ${ }^{147}$

Deciding not to decide is one strategy in an age of social distrust. A different approach would involve judicial intervention coupled with a good dose of judicial modesty, particularly by deciding cases in ways that do not foreclose, and even encourage, continued social debate and political activity on issues, along with the possibility of future legal claims that could produce different outcomes. Various attendant devices exist. Courts could, for example, take a narrow view of the precedential effect of decided cases, such as by limiting the precedent to particularized issues of law or to specific issues of fact rather than as resolving more general issues. ${ }^{148}$ An instructive line in the Court's modern death penalty jurisprudence exemplifies the approach. Despite regular efforts to persuade the Court to invalidate capital punishment wholesale, the Court has instead invalidated the death penalty only in very specific circumstances, for example, for rape of an adult woman; ${ }^{149}$ for murder absent certain aggravating factors; ${ }^{150}$ if the defendant is insane; ${ }^{151}$ and for crimes committed at age

145. Id. at 710 (Roberts, C.J., dissenting). Roberts is surely wrong. The case involved a federal constitutional challenge to state laws, the sort of thing federal courts hear and decide all the time. At the end of his dissent, Roberts wrote the following:

If you are among the many Americans-of whatever sexual orientation-who favor expanding same-sex marriage, by all means celebrate today's decision. Celebrate the achievement of a desired goal. Celebrate the opportunity for a new expression of commitment to a partner. Celebrate the availability of new benefits. But do not celebrate the Constitution. It had nothing to do with it.

Id. at 713. This, too, must be wrong. One might disagree with the majority's constitutional ruling. But it doesn't follow that that the Constitution has "nothing to do" with the outcome in a constitutional case.

146. Id. at 687 .

147. Id. at 698-99.

148. See, e.g., Bush v. Gore, 531 U.S. 98, 109 (2000) (per curiam) (in holding that the statewide manual recount ordered by the Florida Supreme Court during the 2000 presidential election violated the Equal Protection Clause of the Fourteenth Amendment because of a lack of uniform recount standards, stating that "[o]ur consideration is limited to the present circumstances, for the problem of equal protection in election processes generally presents many complexities.").

149. Coker v. Georgia, 433 U.S. 584 (1977).

150. Godfrey v. Georgia, 446 U.S. 420 (1980).

151. Ford v. Wainwright, 477 U.S. 399 (1986). 


\section{fifteen or younger. ${ }^{152}$}

Courts might also take a relaxed approach to stare decisis so as to allow different individuals or groups to bring cases and press their views, even if the issues presented replicate or mirror in significant respects those decided in past litigation. ${ }^{153}$ Here, again, capital punishment is illustrative: with some regularity, the Court has been willing to overturn its prior death penalty cases. ${ }^{154}$ Vertical stare decisis might also take relaxed form, such that, for example, small differences of fact or law could be a legitimate basis for a lower court declining to apply a ruling of the Supreme Court ${ }^{155}$ and lower courts would be free, as they apply past Supreme Court decisions, to anticipate a near-future overruling. ${ }^{156}$ The Court itself, or individual Justices, might regularly signal a willingness to hear additional cases on an issue

152. Thompson v. Oklahoma, 487 U.S. 815 (1988).

153. See, e.g., Gamble v. United States, 139 S.Ct. 1960, 1984 (2019) (Thomas, J., concurring) ("In my view, if the Court encounters a decision that is demonstrably erroneous-i.e., one that is not a permissible interpretation of the text-the Court should correct the error, regardless of whether other factors support overruling the precedent."); FEC v. Wisconsin Right to Life, 551 U.S. 449, 500 (2007) (Scalia, J., concurring in part) (observing that stare decisis is "a principle of policy, and this Court has a considered practice not to apply that principle of policy as rigidly in constitutional as in nonconstitutional cases.") (internal quotations and citations omitted).

154. For example, the Court held in 1989, in Stanford v. Kentucky, 492 U.S. 361 (1989), that the death penalty could be imposed for crimes committed at age 16 or 17, but then overruled that decision in 2005 in Roper v. Simmons, 543 U.S. 551 (2005). In 1989, in Penry v. Lynaugh, 492 U.S. 302 (1989), the Court held that there was no bar to executing a mentally retarded defendant, but overruled that decision thirteen years later in Atkins $v$. Virginia, 536 U.S. 304 (2002). In 1990, in Walton v. Arizona, 497 U.S. 639 (1990), the Court held that a judge could find the requisite aggravating factors for imposition of the death penalty. In 2002, in Ring v. Arizona, 536 U.S. 584 (2002), the Court held these factors must be found by a jury.

155. See, e.g., June Med. Servs. v. Gee, 905 F. 3d 787, 805-10 (5th Cir. 2018) (holding that a Louisiana law regulating abortion providers, though near-identical to the Texas law invalidated by the Supreme Court in Whole Woman's Health v. Hellerstedt, 136 S. Ct. 2292 (2016), was valid because, as a factual matter, it generated more benefits and imposed fewer burdens than did the Texas statute the impact and distinguishing a Louisiana abortion law), rev'd by June Med. Servs. v. Russo, 140 S. Ct. 2103 (2020). See also June Med. Servs., 140 S. Ct. at 2133-34 (2020) (Roberts, J., concurring) ("I joined the dissent in Whole Woman's Health and continue to believe that the case was wrongly decided.... [But] [t]he legal doctrine of stare decisis requires us, absent special circumstances, to treat like cases alike. The Louisiana law imposes a burden on access to abortion just as severe as that imposed by the Texas law, for the same reasons. Therefore Louisiana's law cannot stand under our precedents.”).

156. The Supreme Court has rejected this possibility. See, e.g., Agostini v. Felton, 521 U.S. 203, 237 (1997) ("We reaffirm that if a precedent of this Court has direct application in a case, yet appears to rest on reasons rejected in some other line of decisions, the Court of Appeals should follow the case which directly controls, leaving to this Court the prerogative of overruling its own decisions.") (internal quotation omitted). 
and invite litigants to bring those cases to the Court. ${ }^{157}$ Courts that reject facial challenges to statutes could nonetheless routinely invite and consider separately as-applied challenges: ${ }^{158}$ that, too, is an approach that allows for rather than closes off, ongoing social and political debate.

On the other hand, there is some reason to conclude that the Supreme Court can in fact play a helpful role in resolving contested social issues and so should not shy from the task. Americans have not lost trust in the judiciary in general nor in the Supreme Court in particular. Researchers point to several reasons to account for why public trust in the Court does not much change over time. One explanation is that the Court itself embodies democratic norms for which there is high support, particularly the rule of law and the importance of judicial independence. ${ }^{159}$ Another explanation is that Americans view the Court as different from other political actors and consider the Justices to reach their decisions based on principles rather than politics. ${ }^{160}$ In a 2020 survey, " $56 \%$ of respondents agreed that Supreme Court Justices set aside their personal and political views and make rulings based on the Constitution, the law, and the facts of the case - an increase from $49 \%$ in 2019." "161 In this sense, one's own displeasure with a particular ruling can actually reinforce the idea that the Court acts apart from partisan politics precisely because it issues unpopular decisions. ${ }^{162}$ Americans might therefore

157. One example is the Court's opinion in Harris v. Quinn, 573 U.S. 616 (2014), signaling that it was ready to overturn Abood v. Detroit Board of Education, 431 U.S. 209 (1977), see Quinn, 573 U.S. at 635 ("The Abood Court's analysis is questionable on several grounds."), and then doing just that four years later in Janus v. American Federation of State, County, \& Municipal Employees, Council 31, 138 S. Ct. 2448 (2018).

158. See, e.g., Gonzales v. Carhart, 550 U.S. 124, 167 (2007) (in rejecting challenge to federal Partial-Birth Abortion Ban Act, invoking uncertainty over whether the barred procedure is ever necessary to preserve a woman's health, but explaining that "as-applied challenges to the Act can be maintained" and "[t]his is the proper manner to protect the health of the woman if it can be shown that in discrete and well-defined instances a particular condition has or is likely to occur in which the procedure prohibited by the Act must be used" because "[i]n an as-applied challenge the nature of the medical risk can be better quantified and balanced than in a facial attack.").

159. Michael Zilis \& Rachel Blandau, Judicial Legitimacy, Political Polarization, and How the Public Views the Supreme Court, OXFORD RsCH. ENCYCLOPEDIA POL. 4 (2021).

160. Id.

161. Annenberg Pub. Pol'y CTr. Amid Pandemic and Protests, Civics Survey Finds Americans Know More of Their Rights (Sept. 14, 2020). https://www.annenbergpublicpolicycenter.org/pandemic-protests-2020-civics-surveyamericans-know-much-more-about-their-rights/ [https://perma.cc/RT5Y-GYVT].

162. J. L. Gibson et al., The Supreme Court and the U.S. Election of 2020: Wounds, 
disapprove of individual Supreme Court decisions but they still hold the Court itself in high regard: Bush v. Gore, for example, was extremely unpopular among Democrats but their overall level of support for the Court did not change. ${ }^{163}$

The upshot might be that the Court has plenty of capital to spend and, of all federal governmental institutions, it can intervene to settle contested issues and do so without any or much harm to itself in the process. Here, it is instructive to note that the dissenting Justices in Obergefell were wrong in their predictions about the effects of the majority's refusal to allow the issue of same-sex marriage to be settled through the normal political process. Public support for same-sex marriage has increased since the time of Obergefell; large majorities of Americans, Democrats and Republicans alike, support same-sex marriage; ${ }^{164}$ there is no serious political movement to end same-sex marriage; and there has been no indication that the current Supreme Court is interested in revisiting Obergefell.

Still, in considering the role the Court could play in settling divisive issues, it is important to recall that public support for the Supreme Court is not inevitable. There remains the possibility that very recent events-the refusal of Senate Republicans to hold a confirmation hearing on the nomination of Merrick Garland, the battles over the nomination of Brett Kavanaugh, and the confirmation of Amy Coney Barrett following the electionyear death of Justice Ginsburg - all of which triggered dips in support for the Court among Democrats, will have long-term effects on the public's trust in the Court. ${ }^{165}$ There also remains the possibility that ramped-up criticism by political elites and other commentators will impact how the public views the Court, ${ }^{166}$ such that "[p]artisan polarization may lead the public to perceive the Court as an increasingly politicized institution," thus eroding the perception of neutrality that has long been a basis for the Court's support. ${ }^{167}$ As this Essay goes to press, national surveys conducted

Self-Inflicted or Otherwise?, 33 BRIT. J. POL. SCI. 535. 535 (2003).

163. Id. at 554 .

164. Justin McCarthy, Record-High 70\% in U.S. Support Same-Sex Marriage, GALLUP (June 8, 2021), https://news.Gallup.com/poll/350486/record-high-support-same-sexmarriage.aspx [https://perma.cc/39CX-Y9N2] (reporting that in 2021, 70\% of Americans favor same-sex marriage, up from $60 \%$ in 2015 when Obergefell was decided).

165. Zilis \& Blandau, supra note 159 , at 6-7.

166. Id. at 8 .

167. Id. at 9-10. 
in the fall of 2021 report declines from prior years in public approval of the Supreme Court and in levels of public trust in the federal judicial branch. ${ }^{168}$ It remains to be seen whether those declines represent a momentary dip or the beginning of a more permanent reorientation. Regardless, even when the public generally trusts courts, high levels of social mistrust and of distrust in other federal institutions might represent a precarious context for judicial efforts to bring to close divisive social issues.

\section{CONCLUSION}

Democracy and Distrust helpfully identifies trust as relevant to the nature and scope of judicial review, but Ely's own account of trust is undeveloped. This Essay has sought to lay out some ways in which a more comprehensive understanding of trust, and in particular of political and social trust as distinct concepts, can usefully inform the democracy-preserving role of courts that Ely emphasizes. In addition, the Essay has sought to sketch some ways in which judicial review might appropriately change in response to changes in trust citizens place in their institutions of government and in each other. Democracy and Distrust remains highly influential forty years after publication. Greater attention to trust can only enhance the book's continued significance.

168. Gallup, Supreme Court, https://news.gallup.com/poll/4732/supreme-court.aspx [https://perma.cc/KW8K-PEN3] (last visited Nov. 5, 2021) (reporting that in a survey conducted in September 2021, 40\% of respondents expressed approval of the way the Supreme Court is handling its job, down from $53 \%$ a year before; and that $54 \%$ of respondents had a "great deal" or "fair amount" of trust in the federal judicial branch, down from $67 \%$ the previous year). 
